\title{
Knowledge and Social Capital: Drivers for Sustainable Local Growth*
}

\author{
Paola Demartini \\ University of Rome Tre, Rome, Italy \\ Mara Del Baldo \\ University of Urbino “Carlo Bo”, Urbino, Italy
}

\begin{abstract}
This paper presents a knowledge resources perspective for territorial competitiveness and sustainability. The latter is defined as a pathway promoted by a plurality of public and private actors, in the for-profit and non-profit sectors, who find that relationships and social cohesion are the drivers for the construction of shared territorial governance. This study integrates an extensive literature review with data from longitudinal empirical research. Authors have adopted the methodology of qualitative research-based case study. In particular, this paper focused the analysis on a project of territorial governance promoted in the Marches region of Italy. This region was selected as a case study, because it is emblematic of the Italian context; the territory is characterized by small businesses diffused throughout the socio-economic fabric and by the proactive role taken by local governments. The perspective offers a powerful instrument for raising awareness of the gaps that local policymakers should address through their initiatives in the knowledge economy.
\end{abstract}

Keywords: knowledge, social capital, sustainable development, regional network, local growth

\section{Introduction}

Researchers in different disciplines within the social sciences have recognized that regions are an important focus of analysis, because political and social production processes and interactions take place there (Tomaney \& Ward, 2000; Moulaert \& Sekia, 2003; Becattini, 2004). Consequently, regional analyses must become far more central to research and policy formulation in competitiveness and economic development. Since many of the essential determinants of economic performance seem to reside in regions, national policies are necessary but not sufficient, and much of economic policy should be decentralized at the meso-level (Porter, 2003).

The importance of regions may explain why countries with greater economic decentralization, such as Germany, USA, and Italy, have been historically successful. It may also explain why certain provinces or states in countries such as China and India have recently experienced growth rates dramatically higher than others.

\footnotetext{
*Acknowledgement: This paper is the product of a joint research project. However, Mara Del Baldo has written "Introduction", "A Literature Review on Regional Social Responsibility and on Knowledge Assets at a Meso-level" and "Interpreting the Case Study Through the Lens of the Suggested Conceptual Framework", Paola Demartini has written all the other sections.

Paola Demartini, full professor of Accounting, University of Rome Tre, Rome, Italy.

Mara Del Baldo, associate professor of Accounting, University of Urbino "Carlo Bo", Urbino, Italy.

Correspondence concerning this article should be addressed to Paola Demartini, University of Rome Tre, via Silvio D'amico 77, 00100, Roma, Italy. E-mail: paola.demartini@uniroma3.it.
} 
However, before planning policies for territorial governance, it is important to disentangle the specific key factors underpinning the strength and vitality of a regional economy.

In the light of these considerations, this research question is the following: What are the critical resources affecting the sustainable growth of regional economies (World Commission on Environment and Development, 1987)?

In order to answer this question, this paper will combine two different but complementary streams of research.

A first stream of research emphasizes the role of required intangible factors (rules and values "rooted" in the territorial community from which convergent norms and behaviors are produced) that allow the positive evolution of a business context: ethics, legality, social cohesion, and sustainable development (Del Baldo, 2009, 2012; Del Baldo \& Demartini, 2012a).

The second stream of research identifies assets such as those critical and strategic knowledge resources that affect a specific regional system's performance and processes of value creation (Teece, 2000; Marr \& Schiuma, 2001; Marr, Schiuma, \& Neely, 2004; Boschma; 2004; Bounfour \& Edvinsson, 2005; Schiuma, Lerro, \& Carlucci, 2005, 2008; Lerro \& Carlucci, 2007; Schiuma \& Lerro, 2008; Lerro \& Schiuma, 2009; Lerro, 2011).

Building on these two streams of research, this paper aims at drawing an interpretative framework in order to identify the intangible drivers influencing regional systems' competitiveness and sustainable growth.

This will then serve as the framework for analyzing a particular experience of territorial governance promoted in the Marches region. The latter was selected as a case study, because it is emblematic of the Italian context; indeed, the territory is characterized by the diffuse presence of small businesses in the socio-economic fabric and by the proactive role of the local government.

This paper proceeds as follows: First, a literature review is presented in order to draw an interpretative framework; then the research methodology and the findings of the analysis are presented. Finally, conclusions follow. To explore this question, authors contacted a broad national sample of U.S. lawyers who predicted their chances of achieving their goals in real-life cases and provided confidence ratings in their predictions.

\section{Theoretical Framework}

\section{A Literature Review on Regional Social Responsibility}

Recently, the economic literature is turning its attention to the universe of the SMEs in order to verify and support their role in promoting corporate social responsibility (CSR) and forms of sustainable territorial development (Carroll, 1999; European Commission, 2002; European Union, 2004; Spence \& Schmidpeter, 2003; Spence, Habisch, \& Schmidpeter, 2003; Spence, Schmidpeter, \& Habisch, 2004; Perrini, 2006).

Researchers agree that good CSR practices are linked to and reinforced by the personal characteristics of small entrepreneurs who are deeply rooted in their socio-economic context. In particular, CSR depends on the entrepreneur's ethical orientation and values (Morsing, 2006; Longenecker, Moore, Petty, Palich, \& McKinney, 2006).

As far as Italy is concerned, the above-mentioned values spring from a mix of rural culture and an urban culture stemming from Renaissance Humanism, which provides the basis of Italy's civil economy and is considered as the heritage of the nation (Bagnasco, 1981, 2004; Putnam, 1993; Del Baldo, 2010).

When there is a common aim to improve the quality of life that bind individuals and organizations 
belonging to the same territory, it is possible to introduce the notion of territorial social responsibility founded on the rediscovery of shared values, such as identity and a sense of belonging to a precise cultural and ethical context, which the territory's economic, social, and institutional actors know how to reinforce, thanks to solid networks of relationships (Del Baldo \& Demartini, 2012a, 2012b).

The sharing of values and behavior patterns - creating a climate of collaboration and dialogue and to establish a set of relationships between different actors - generates the relational infrastructure of the territory, its capital context, its ability to express intangibles that are distinctive and difficult to reproduce elsewhere, and the ability to generate socio-economic development. This "territorial capital" is linked to the concept of social capital as a set of beliefs, norms, traditions, and attitudes that drive the behaviour of individuals and organizations belonging to a definite community (Bourdieu, 1985).

However, this approach can be applied only in specific social and economic contexts, where all local actors have absorbed a common culture that spreads in trust and mutual values with respect to the way business is run.

As the literature poses (Becattini, 1990), there are some territories in Italy (such as the Marches region-along with other Italian territories such as Tuscany, Emilia Romagna, and the Veneto) that are characterized by an environment in which local actors share a collective identity based on the history of the region where they live (Bagnasco, 2004; Putnam, 1993; Del Baldo \& Demartini, 2012a).

In those regions where the sharing of values and behaviour patterns create a climate of trust and collaboration, the routes of sustainable development are based on the capability to take part in (as well as to activate) networks which include several actors: institutions such as municipal, provincial, and regional authorities; enterprises; trade and entrepreneurial associations, consumer and non-profit organizations; universities; chambers of commerce, banks, and etc.. These networks, whose goals are to promote a model of sustainable economic development, are assets of territorial relational capital (Figure 1).

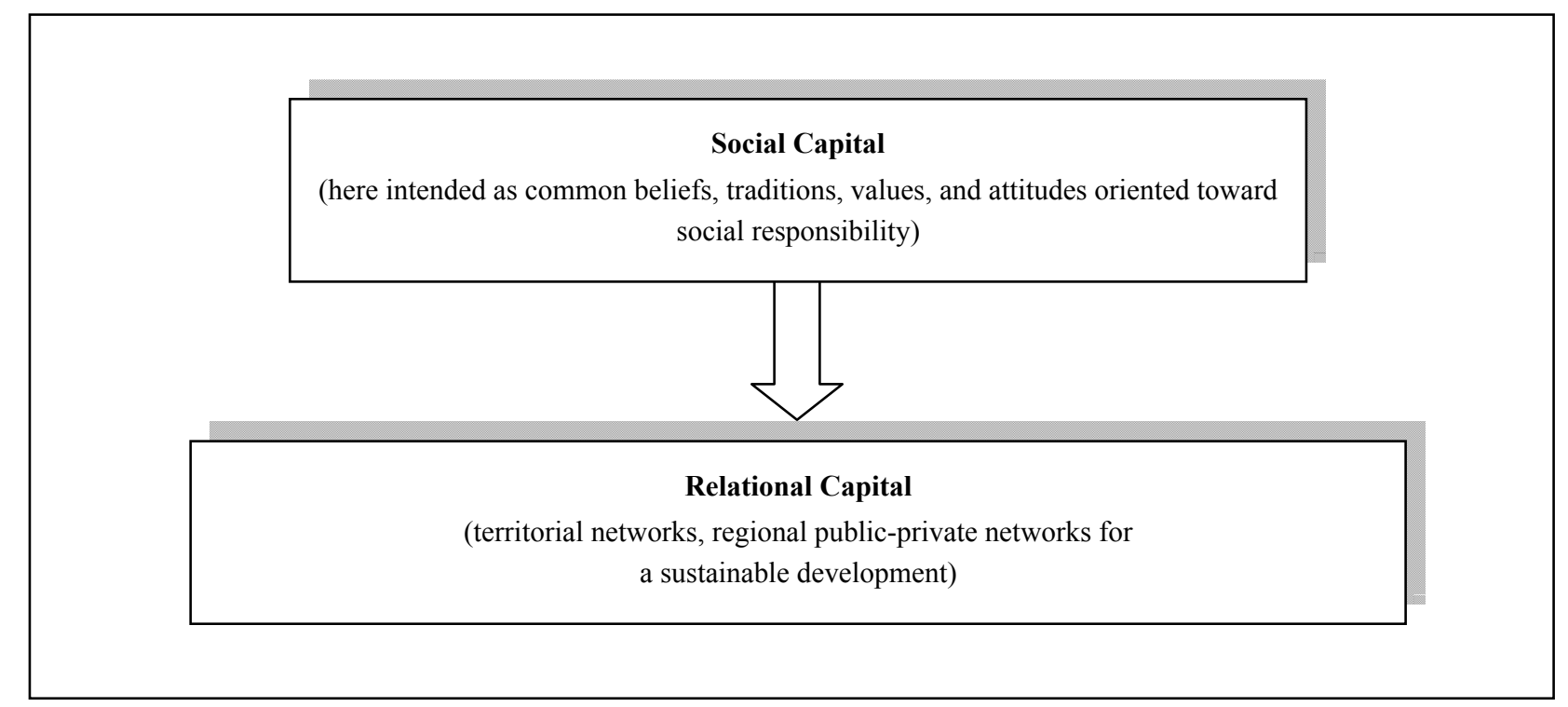

Figure 1. Key intangible assets as per the territorial social responsibility perspective.

\section{A Literature Review on Knowledge Assets at a Meso-level}

The concept of a "knowledge-based economy" acknowledges that knowledge represents a key strategic 
source of growth and wealth creation in today's complex business environment (Teece, 2000; Marr \& Schiuma, 2001; Marr et al., 2004; Perrini \& Vurro, 2010).

Lerro and Schiuma (2009) identified knowledge assets as those critical and strategic knowledge resources affecting a specific organizational and territorial system's performance and processes of value creation: human capital, structural capital, and relational capital (Dakhli \& De Clerq, 2004; Huggins, 2003; Iyer, Kitson, \& Toh, 2005; Sanchez Medina, Melian Gonzales, \& Garcia Falcon, 2007; Bontis, 2004; Pasher \& Shachar, 2005; Noronha Vaz \& Nijkamp, 2009).

The first category (human capital) pertains to people's skills, knowledge, and expertise, which allow the individual to foster innovations, changes in activities, and economic growth (Coleman, 1988). Human capital can be developed through formal training and education (Dakhli \& De Clercq, 2004). Better educated people, with more extensive work experience and an interest in investing more time, energy, and resources into improving their skills, are more inclined to provide higher benefits for themselves and at the same time are better able to contribute to the overall well-being of the society (Schiuma \& Lerro, 2008).

With reference to a regional context, human capital essentially comprises the know-how characterizing the different actors operating within a region. In some cases, the know-how may reside in the individuals; in other cases, the know-how may be collectively owned by region's stakeholders (Schiuma \& Lerro, 2008).

The second asset-relational capital and networking capabilities-represent another factor that is fundamental for innovation (Rondè \& Hussler, 2005). Numerous scientific and policy contributions have outlined the importance of formal and informal relationships among the different regional stakeholders to activate and sustain value creation dynamics (Piore \& Sabel, 1984; Becattini, 1990; Brusco, 1982; Storper, 2005; Cappellin, 2003).

Some researchers linked the diversity and the cooperation of local networks with theories concerning organizational learning, underlining the importance of the cognitive processes involving the different actors of a network (Nonaka \& Konno, 1998). This approach is strongly based on the concept of a "learning region", which posits that a local system's ability to evolve is strictly related to its capacity to sustain a continuous learning process (Maillat \& Kebir, 1999).

Thirdly, the importance of structural capital emerges as a knowledge-based dimension that grounds region' capacity for innovation (Lambridinis, Psycharis, \& Rovolis, 2005; Schiuma et al., 2008). Structural capital includes all of those assets which are tangible in nature but play a fundamental role in the development, acquisition, management, and diffusion of knowledge at the regional level. A relevant component of structural capital is represented by technological infrastructures, which support a region's capacity for innovation. These include information communication technology (ICT), digital communication systems, and networks. Moreover, particular attention should be paid toward the fundamental role of local firms as repositories for knowledge that can activate and sustain virtuous pathways for regional development. Other regional knowledge repositories are universities and research centers.

Finally, social capital (Nahapiet \& Ghoshal, 1998) is a special component of regional structural capital (Adler \& Kwon, 2002; Lerro \& Carlucci, 2007; Schiuma et al., 2005, 2008). Social capital comprises knowledge assets related to the soft infrastructure of a region, which are predicated on dynamic interdependencies that link regional actors. The social dimension is a fundamental factor affecting a region's capability to create value, since it is related to stakeholders' social dynamics contained within a 
local system, which includes their values, culture, routines, behaviors, networks, identity, and atmosphere (Figure 2).

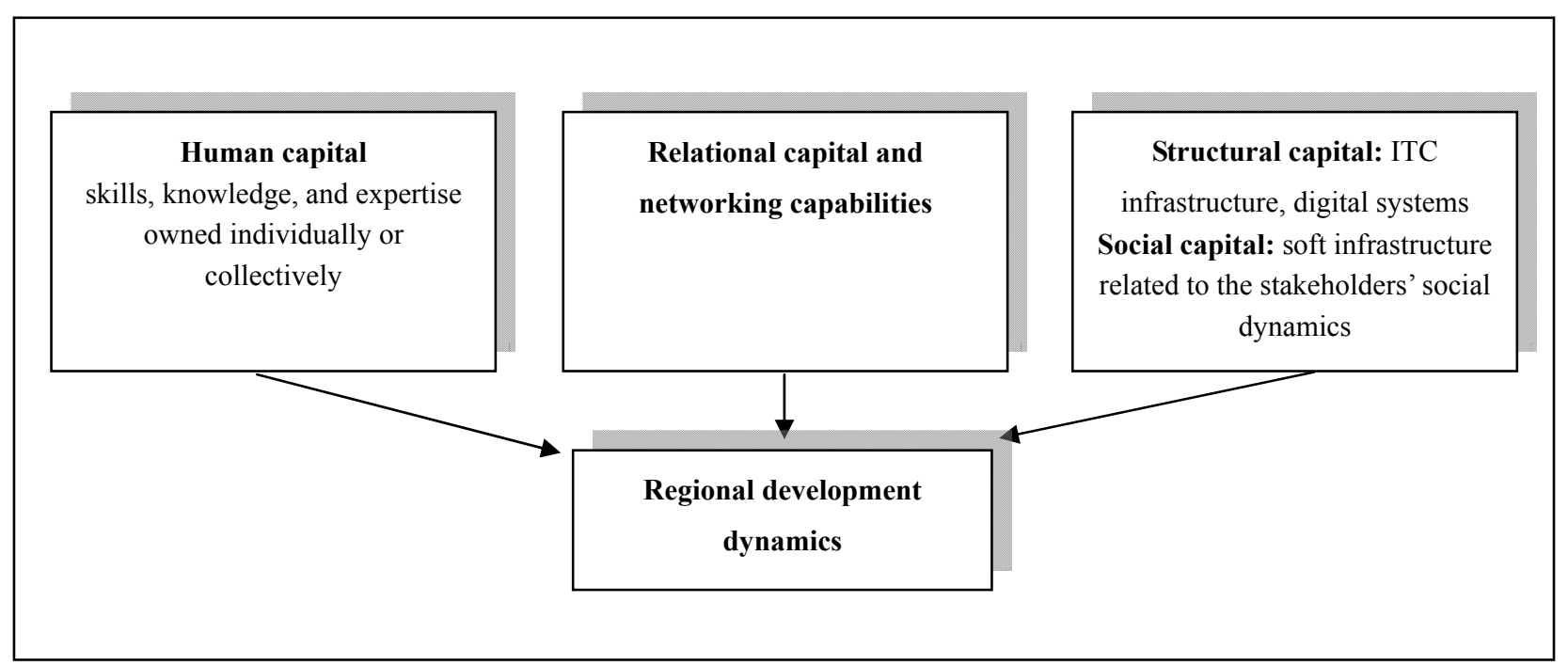

Figure 2. Key intangible assets as per the knowledge-based regional development perspective.

\section{A Conceptual Framework Combining the Two Perspectives}

The idea to combine these two perspectives was suggested in a seminal paper by Porter and Kramer (2011) entitled Creating Shared Value which argued that a new way to achieve economic success would be to develop new skills and knowledge, such as a far deeper understanding of societal needs, the company's productivity, and the ability to collaborate across for-profit and non-profit fields.

With reference to the regional context, Porter and Kramer (2011) suggested that the creation of shared value could enable the development of local clusters, since the success of every company is affected by other connected companies and regional infrastructure. Productivity and innovation are influenced by the concentration of firms, service providers, and logistical infrastructures in particular fields, such as ICT into clusters. Clusters include not only businesses but also research centers, trade associations, and standards organizations. Local clusters provide public benefits, such as high quality schools and universities, fair competition laws, business ethics, and market transparency. While, without a supporting cluster, innovation and productivity suffer.

Building on the above-mentioned stream of research, territorial social responsibility, and regional knowledge-based development, this paper aims to construct an interpretative framework that can identify the intangible drivers influencing the competitiveness and sustainable growth of local systems.

Both of these strands of research emphasize soft intangibles such as common beliefs, traditions, and values which are prerequisite for trust and effective regional stakeholders' interactions.

However, within the first research perspective, these common values are the basis for the orientation of companies and institutions toward social responsibility and sustainability, which is interpreted as a new, individual, and collective capability to create shared value.

Thus, accepting this proposition, authors suggest that social capital (here including values and attitudes oriented toward social responsibility) is the meaningful intangible asset that influences the dynamic capability of regional stakeholders to strengthen the others. 
Authors think that the second strand of research offers an important contribution for understanding the process of sustainable local development through a region's capacity for innovation. The latter includes both the innovation dynamics taking place at the regional level, and those which could be developed by policy and management activities aimed at leveraging local knowledge resources (Lee \& Choi, 2003; Marr, Gupta, Pike, \& Roos, 2003; Darroch, 2005; Noronha Vaz \& Nijkamp, 2009; Andreeva \& Kianto, 2012; Kianto, Ritala, Inkinen, \& Vanhala, 2013).

Moreover, it is important to emphasize that human, relational, and structural capital have a strong impact on the dynamics of regional development. In fact, best practices of local development stem from the combination of several forms of knowledge assets that complement and strengthen one another (Schiuma \& Lerro, 2008).

In light of the above-mentioned propositions, this conceptual framework is depicted in Figure 3 below.

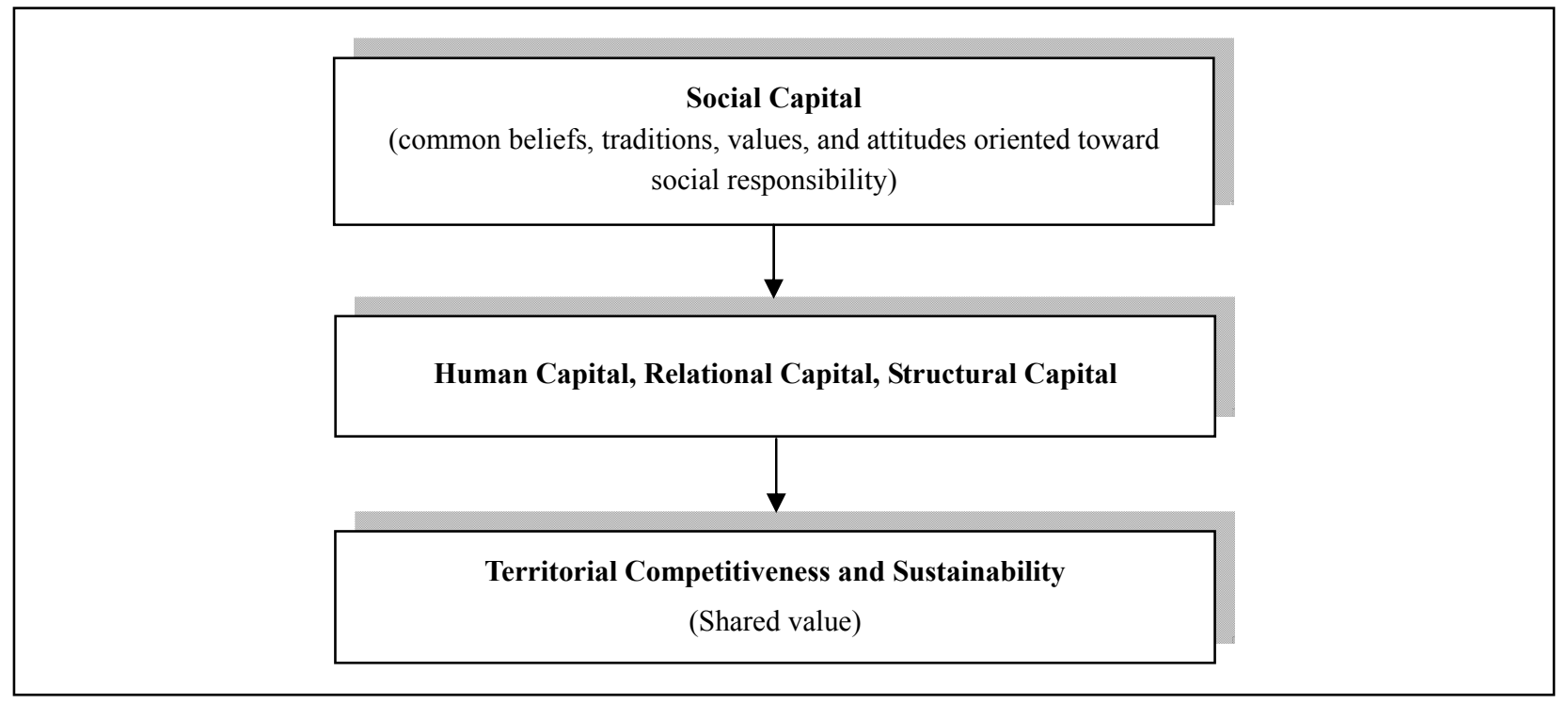

Figure 3. A conceptual framework for territorial competitiveness and sustainability.

\section{Methodology}

This conceptual framework will be applied to a case study of the Marches region. The Marches is of particular interest for two main reasons:

(1) the presence of numerous SMEs who excel in providing for the economic and social well-being of their community. One study by Unioncamere (2014) reveals that $18.3 \%$ of the businesses regarded for their best practices come from the Marches region;

(2) a regional public administration that is particularly sensitive to its citizens' quality of life and to the themes of CSR and sustainability, and, since 2005, has initiated pathways of territorial social responsibility through the projects Sirm and I.Re.M, which will be analyzed below.

The empirical study was developed, according to a qualitative approach and a case study methodology (Yin, 1994) for the dual objectives of detailing the principle characteristics of the phenomena, and for both understanding and analyzing the dynamics of a given process (Lerro \& Schiuma, 2009). Methodologically, the development of a case study represents a strategy of research that is concentrated on the comprehension of the dynamics that characterize specific contexts (Eisenhardt, 1989; Eisenhardt \& Graebner, 2007). 
The analysis was based on information collected in a multi-year period - the first period between October 2009 and November 2010 and the second beginning in the second half of 2013 and continuing up to the first half of 2014 -through in-depth semi-structured interviews as well as informal conversations addressed to regional public administrators from the Marches region (Department "Public sector and labor market"-working group for sustainable development) who are involved in the projects presented below. In addition, interviews were conducted with diverse actors within the regional network: public officials from the provinces, representatives of associations, trade unions, and institutions in the Marche region (i.e. Chamber of Commerce), entrepreneurs and managers of KPMG Advisory Spa (technical partners and coordinator of the I.Re.M project). Authors performed face-to-face interviews of two top managers of Marche region, two public officers, three entrepreneurs, and six professionals. With the permission of the interviewees, the interviews were tape-recorded. The interview format, though semi-structured, allowed additional questions. Authors transcribed approximately 20 hours of interviews, which varied in length from 30 minutes to two hours, averaging 50 minutes each. This transcription greatly facilitated the narrative of the case study that follows. Field notes and informal conversations complemented the taped interviews. The primary data were then combined with secondary data from the public institutions and companies' websites, newspapers, magazine articles, and other internal documents. Finally, authors informally observed the interactions (with internal and external stakeholders) of the network's actors during technical committees, forums, and workshops (triangulation of methods).

First, a narrative description of the selected case study will be presented; next, the investigated phenomenon will be interpreted in the light of the conceptual framework.

\section{Analysis}

\section{Narrative of the Case Study}

What follows is an analysis of the roles and forms of diverse actors in experimental projects promoted by the Marches region, defined as "ethical territorial networks". This term marks a type of coalition among local institutions, businesses, and civic organizations that commit themselves to voluntary, reciprocally advantageous relationships, and follow a common social objective: to improve the quality of life and the quality of work in the Marchegian territory (Retrieved from http:// www.istruzionefoermazionelavoro.marche.i/rsi).

\section{First Marchegian Territorial Network: Marches Region's Responsible Business System}

The Marche region's responsible business system was created in 2005 by a consortium of 120 Marchegian businesses, assisted by institutional partners (among them, the Marche region's social service ministry) and by diverse civic and institutional organizations (trade unions, non-profits, and consumer associations). Its scope was to foster synergy among territories, institutions, businesses, entrepreneurial associations, social actors, and informal networks in civic society, which encouraged firms to adopt best practices of social responsibility. In particular, the project had two principal goals: to institute a regional registry for SMEs, agricultural businesses, non-profits, and public administration organizations that adopt and promote socially responsible practices; and to fund the implementation of socially responsible systems by local public administrators, non-profits, agricultural businesses and SMEs in the Marches region. The initiative involved a pilot sample of small and medium-sized Marchegian businesses (19 companies).

\section{The Second Phase: The I.Re.M. Projec-Responsible Businesses of the Marche Region}

The Marche region's I.Re.M. (2009-2010) aimed to improve the inroads already made with Sirm in 2005 
by inaugurating a second phase of the model of Marchegian social responsibility. Specifically, the objectives of the project included creating a regional CSR system; developing regional CSR guidelines; implementing a CSR code of conduct; extending the test to 50 firms in all sectors, with a particular focus on the footwear and furniture industries; developing and applying the designation of socially responsible business; and creating a database of socially responsible enterprises, organized by the level of responsibility they have achieved, which can be accessed from the Marche region's website. The advantages for the participating actors and their respective roles were clearly identified through a network instrument and reciprocal comparisons (Table 1).

Table 1

Roles and Advantages of Network Actors

\begin{tabular}{|l|l|}
\hline Role of actors & Advantages of participating actors \\
\hline $\begin{array}{l}\text { Associations and representative organizations } \\
\text { Raise awareness among associates to favor participation in the } \\
\text { project and to bring associations into project development } \\
\text { initiatives. }\end{array}$ & $\begin{array}{l}\text { Associations and representative organizations } \\
\text { Create opportunities for their associates and promote the } \\
\text { development of an entrepreneurial culture that is responsible } \\
\text { and attentive to innovation. }\end{array}$ \\
\hline $\begin{array}{l}\text { Large-scale businesses } \\
\text { Plan meetings between SME providers (i.e., workshops) to } \\
\text { create a "responsible supply chain" }\end{array}$ & $\begin{array}{l}\text { Large-scale businesses } \\
\text { Utilize the IREM project to formalize the development of a } \\
\text { socially responsible supply chain. }\end{array}$ \\
\hline $\begin{array}{l}\text { Small businesses } \\
\text { Participate in the experimental phases of the project. }\end{array}$ & $\begin{array}{l}\text { Small businesses } \\
\text { Benefit from the support of a society of external consultancy to } \\
\text { utilize guidelines, put in place pathways of social responsibility, } \\
\text { and valorize intangible capital. }\end{array}$ \\
\hline
\end{tabular}

\section{The Third Phase: Toward an Interregional Network}

In February 2013, the Marche region signed an agreement with 11 other Italian Regions to launch an inter-regional project with the scope of collaborating to define common paths for spreading social responsibility. One of the main objectives is to share the results of these programs from different local experiences.

\section{Interpreting the Case Study Through the Lens of the Suggested Conceptual Framework}

In Table 2 below, the investigated case study will be outlined in the light of the conceptual framework. In particular, this paper will apply it to the projects promoted by local authorities of the Marche region to enhance business responsibility. The aim is to assess if these initiatives have succeed in strengthening the effective intangible key factors and promoting a regional sustainable development.

Table 2

Intangibles Output of the Marche Region Project

\begin{tabular}{|c|c|c|}
\hline Social Capital & & \\
\hline Appreciating the importance of Marchegiar & n culture and traditions & \\
\hline Human Capital & Relational Capital & Structural Capital \\
\hline $\begin{array}{l}\text { - Learning about other national and } \\
\text { international experiences } \\
\text { - Training for certification in ISO 9001, } \\
\text { OHSAS 18001, ISO 14001, and SA } \\
8000 \text { management systems }\end{array}$ & - Multi-stakeholder forums & $\begin{array}{l}\text { Development of instruments of external } \\
\text { communication (i.e. sustainability } \\
\text { scorecard) } \\
\text { - However, the process of adhering to the } \\
\text { system, outlining the process of } \\
\text { recognition, and rewarding (awards, } \\
\text { incentives and fiscal relief, tax breaks) } \\
\text { has only been envisioned and not } \\
\text { implemented. }\end{array}$ \\
\hline
\end{tabular}

The experimental phase produced a number of positive results.

In particular, it allows for the analysis of the state of CSR within the participating businesses, which 
helps define the values contained in their codes of conduct and appreciate the importance of Marchegian culture and traditions. It also helps businesses to more clearly define their sustainability profile. It also helped every firm identify aspects for improvement, so that they could embark on a pathway of social responsibility; grow in their understanding of the importance of the adoption of socially responsible practices by learning about other national and international experiences; and develop instruments to monitor and manage CSR processes.

The interaction among network actors has also helped redefine base indicators of the territory, of the operative sectors, and of the different business typologies; it also improved the process of defining a minimum level of social responsibility and paying particular attention to the most diffuse management models. Finally, it helped develop instruments of external communication through a "sustainability scorecard".

Nevertheless, authors should not consider the project as finished, but rather the beginning of a future phase. Stemming from participants' evaluations of the multi-stakeholders forum and from the needs expressed by the territory's businesses and stakeholders, this future phase should accomplish the following objectives: first, to introduce criteria for different levels of evaluation and for developing cohesion within a regional system; second, to implement a rewards system; and third, to institute a permanent, independent supervisory organism to check the regional system.

\section{Conclusions}

The following reflections are articulated around two points that focus on the most relevant aspects emerging from the analysis.

\section{Awareness of Key Intangibles for Territorial Competitiveness and Sustainability}

The study of businesses and their territories was first framed by the perspective of univocal observation. More recently, the hypothesis of the co-evolution of subjects and contexts was suggested, emphasizing both how the evolution of the firm is more than just simple adaption to outside environmental factors, and how it is essential to penetrate the sustentative mechanisms to "capture" driving factors.

This key reading considers firms and territories as systems that are partially or relatively open, dynamic, and contextualized in time and space. Each system possesses a critical resource, and both search for a common logic for coexisting in a way that both derive mutual direct and indirect benefits at the micro-and meso-economic levels (Del Baldo, 2012).

This holistic development requires the diffusion of soft factors (common rules and values from which shared norms and behaviors are produced) that help the positive evolution of the business-context: ethics, legality, and social cohesion.

Thus authors deem that sustainable regional development requires the strengthening of key intangibles at the local level. This includes reinforcing social capital (ethics, legality, social cohesion, and attitudes oriented toward social responsibility), human capital (skill, knowledge, and expertise owned individually or collectively), and high-quality knowledge-based infrastructures, which play a fundamental role in the development, acquisition, management, and diffusion of implicit and explicit knowledge at the regional level (stored in depositories such as schools and academic programs, research centers, ITC infrastructure, digital systems, and etc.). These are the prerequisites for creating shared value and enabling cluster development.

To enhance the above-mentioned key intangibles, networks of public, for profit and non-profit organizations play a central role. 


\section{Role of Synergistic Networks}

Porter $(1998,2003)$ argued that a company's purpose must be redefined by re-evaluating the importance of its "proximity" and its "local source of uniqueness", as well as its need to participate actively by "engaging locally" in order to improve the local business environment and the local social capital, "because the health of the local business environment is important to the health of the company" (Porter, 1998, p. 88). Porter and Kramer (2011) also emphasized the need of working collectively — public and private - to create the conditions that promote sustainable growth. Governments, both national and local, have new roles to play, and in their industrial policy they "should strive to create an environment that supports rising productivity" (Porter \& Kramer, 2006, p. 89).

The findings suggest that CSR and sustainability projects are planned and implemented by public, for-profit, and non-profit organizations. The presence of non-profits-whose goals are not linked to producing profit, but to CSR itself-is essential to systematically guarantee levels of social responsibility. Stable and collaborative relations among these three types of organizations provide the foundation for mixed and synergistic networks (Gerencser, Van Lee, Napolitano, \& Kelly 2008).

Different actors can play different roles in the development of CSR and sustainability-oriented networks. The role of informer and educator, as well as the role of the regulator, quality controller, and supervisor of CSR and sustainability is the realm of public organizations, which institutionally represents the interests of civil society. The role of the motivator and visionary is typical of the non-profit sector. Finally, the role of stimulus and catalyst can be assumed by public organizations, non-profit organizations, or private companies acting in synergy.

Finally, authors deem that the role of the public organization is fundamental —at the local, national, and international levels - but it becomes effective and proactive only when public institutions works in synergy with the actors of the for-profit and non-profit world, overcoming fragmented visions. Integration fosters interesting convergences and pathways of multi-sector networks mixing public/private/non-profit organizations, in which CSR, sustainability, and performance growth, can be reached, if each actor plays its role correctly.

\section{References}

Adler, S., \& Kwon, S. (2002). Social capital: Prospects for a new concept. The Academy of Management Review, 27(1), 17-40.

Andreeva, T., \& Kianto, A. (2012). Does knowledge management really matter? Linking KM, practices, competitiveness and economic performance. Journal of Knowledge Management, 16(4), 617-636.

Bagnasco, A. (1981). Labour markets, class structure, and regional formations in Italy. International Journal of Urban and Regional Research, 5, 40-44.

Bagnasco, A. (2004). Trust and social capital. In K. Nash, \& A. Scott (Eds.), The blackwell companion to political sociology (pp. 230-239). Oxford: Blackwell.

Becattini, G. (1990). The Marshallian industrial districts as a socio-economic notion. In F. Pyke, G. Becattini, \& W. Sengenberger (Eds.), Industrial districts and inter-firm cooperation in Italy (pp. 37-51). Geneve: International Institute for Labour Statistic.

Becattini, G. (2004). Industrial district: A new approach to industrial change. Cheltenham: Edward Elgar.

Bontis, N. (2004). National intellectual capital index-A United Nations initiative for the Arab region. Journal of Intellectual Capital, 5(1), 13-39.

Boschma, R. A. (2004). Competitiveness of regions from an evolutionary perspective. Regional Studies, 38(9), 991-999.

Bounfour, A., \& Edvinsson, L. (2005). Intellectual capital for communities. Boston: Elsevier Butterworth-Heinemann.

Bourdieu, P. (1985). The forms of social capital. In J. G. Richardson (Ed.), Handbook of theory and research for the sociology of education (pp. 241-258). New York: Greenwood. 
Brusco, S. (1982). The Emilian model: Productive decentralization and social integration. Cambridge Journal of Economics, 6(2), 167-184.

Cappellin, R. (2003). Territorial knowledge management: Towards a metrics of the cognitive dimension of agglomeration economies. International Journal of Technology Management, 26(2/3/4), 303-332.

Carroll, A. B. (1999). Corporate social responsibility. Business and Society, 38(3), 268-295.

Coleman, J. S. (1988). Social capital in the creation of human capital. The American Journal of Sociology, 94, 95-120.

Dakhli, M., \& De Clerq, Q. D. (2004). Human capital, social capital, and innovation: A multi-country study. Entrepreneurship \& Regional Development, 16(2), 107-128.

Darroch, J. (2005). Knowledge management, innovation and firm performance. Journal of Knowledge Management, 9(3), 101-115.

Del Baldo, M. (2009). Corporate social responsibility and corporate governance in Italian SMEs: An analysis of excellent stakeholders relationship and social engagement profiles. In C. Jayacharndran, U. Subramanian, \& U. Rudy (Eds.), Striving for competitive advantage \& sustainability (pp. 1515-1524). Bratislava: Montclair State University, NJ \& Comenius University in Bratislava.

Del Baldo, M. (2010). Corporate social responsibility and corporate governance in Italian SMEs: Toward a "territorial" model based on small "champions" of CSR. International Journal of Sustainable Society, 2(3), 215-247.

Del Baldo, M. (2012). Corporate social responsibility and corporate governance in Italian SMEs: the experience of some "spirited businesses. Journal of Management and Governance, 16(1), 1-36.

Del Baldo, M., \& Demartini, P. (2012a). Small business social responsibility and the missing link: The local context. In W. D. Nelson (Ed.), Advances in business management (pp. 69-94). New York: Nova Science Publishers.

Del Baldo, M., \& Demartini, P. (2012b). Bottom-up or top-down: Which is the best approach to improve CSR and sustainability in local contexts? Reflections from Italian experiences. Journal of Modern Accounting and Auditing, 8(3), 381-400.

Eisenhardt, K. M. (1989). Building theories from case study research. Academy of Management Review, 14(4), 532-550.

Eisenhardt, K. M., \& Graebner, M. E. (2007). Theory building from cases: Opportunities and challenges. Academy of Management Journal, 50(1), 25-32.

European Commission. (2002). European SMEs and social and environmental responsibility. Luxemburg: Enterprise Publications.

European Union. (2004). European multi-stakeholder forum on CSR: Report of the round table on fostering CSR among SMEs. Luxemburg: Enterprise Publications.

Gerencser, M., Van Lee, R., Napolitano, F., \& Kelly, C. (2008). Megacommunities: How leaders of government, business, and non-profits can tackle global challenger together. Great Britaing: Palgrave MacMillan.

Huggins, R. (2003). Creating a UK competitiveness index: Regional and local benchmarking. Regional Studies, 37(1), 89-96.

Iyer, S., Kitson, M., \& Toh, B. (2005). Social capital, economic growth, and regional development. Regional Studies, 39(8), $1015-1040$.

Kianto, A., Ritala, P., Inkinen, H., \&Vanhala, M. (2013). The interaction of intellectual capital stocks and knowledge management practices in organizational value creation. Proceedings from the 8th International Forum on Knowledge Asset Dynamics 2013, Zagreb.

Lambridinis, M., Psycharis, Y., \& Rovolis, A. (2005). Regional allocation of public infrastructure investment: The case of Greece. Regional Studies, 39(9), 1231-1244.

Lee, H., \& Choi, B. (2003). Knowledge management enablers, processes, and organizational performance: An integrative view and empirical examination. Journal of Management Information Systems, 20(1), 179-228.

Lerro, A. (2011). A stakeholder-based perspective in the value impact assessment of the project. Valuing intangible assets in Scottish renewable SMEs. Measuring Business Excellence, 15(3), 3-15.

Lerro, A., \& Carlucci, D. (2007). Intellectual capital and regions: Origins, theoretical foundations, and implications for decision makers. International Journal of Learning and Intellectual Capital, 4(4), 357-376.

Lerro, A., \& Schiuma, G. (2009). Knowledge-based dynamics of regional development: The case of Basilicata region. Journal of Knowledge Management, 13(5), 287-300.

Longenecker, J. G., Moore, C. W., Petty, J. W., Palich, L. E., \& McKinney, J. A. (2006). Ethical attitudes in small business and large corporations: Theory and empirical findings from a tracking study spanning three decades. Journal of Small Business Management, 44(2), 167-183.

Maillat, D., \& Kebir, L. (1999). Learning region et systèmes teritoriaux de production. Revue d'Economie Régional et Urbaine, 3 , 430-448.

Marr, B., \& Schiuma, G. (2001). Measuring and managing intellectual capital and knowledge assets in new economy organizations. In M. Bourne (Ed.), Handbook of performance measurement (pp. 1-30). London: Gee Publishing. 
Marr, B., Gupta, O., Pike, S., \& Roos, G. (2003). Intellectual capital and knowledge management effectiveness. Management Decision, 41(8), 771-781.

Marr, B., Schiuma, G., \& Neely, A. (2004). The dynamics of value creation: Mapping your intellectual performance drivers. Journal of Intellectual Capital, 5(2), 312-325.

Morsing, M. (2006). Drivers of corporate social responsibility in SMEs. Proceedings from the EABIS/CBS International Conference Integration of CSR into SMEs business practice, Copenhagen Business School, Denmark.

Moulaert, F., \& Sekia, F. (2003). Territorial innovation models: A critical survey. Regional Studies, 37(3), 289-302.

Nahapiet, J. \& Ghoshal, S. (1998). Social capital, intellectual capital, and the organizational advantage. Academy of Management Review, 23, 242-266.

Nonaka, I., \& Konno, N. (1998). The concept of 'ba': Building a foundation for knowledge creation. California Management Review, 40, 40-54.

Noronha Vaz, T., \& Nijkamp, P. (2009). Knowledge and innovation: The strings between global and local dimensions of sustainable growth. Entrepreneurship \& Regional Development, 21(4), 441-455.

Pasher, E., \& Shachar, S. (2005). The intellectual capital of the State of Israel. In A. Bounfour, \& L. Edvinsson (Eds.), Intellectual capital for communities, (pp. 97-112). Boston: Elsevier Butterworth-Heinemann.

Perrini, F. (2006). SMEs and CSR theory. Evidence and implications from an Italian perspective. Journal of Business Ethics, 67, 305-316.

Perrini, F., \& Vurro, C. (2010). Corporate sustainability, intangible assets and competitive advantage. Symphonya: Emerging Issues in Management, 2, 1-8.

Piore, M., \& Sabel, C. (1984). The second industrial divide. New York: Basic Books.

Porter, M. E. (1998). Cluster and the new economics of competition. Harvard Business Review, 76(6), 77-90.

Porter, M. E. (2003). The economic performance of Regions. Regional Studies, 37(6/7), 549-578.

Porter, M. E., \& Kramer, M. R. (2006). Strategy \& society: The link between competitive advantage and corporate social responsibility. Harvard Business Review, 84, 78-92.

Porter, M. E., \& Kramer, M. R. (2011). Creating shared value. Harvard Business Review, 89(1/2), 62-77.

Putnam, R. D. (1993). Making democracy work. Civic tradition in modern Italy. Princeton: Princeton University Press.

Regione Marche. (2006). La responsabilità sociale delle imprese marchigiane. Un progetto sperimentale (Corporate social responsibility in the Marche's region. Conclusive report). Retrieved from http://www.istruzionefoermazionelavoro.marche.i/rsi

Rondè, P., \& Hussler, C. (2005). Innovation in regions: What does really matter? Research Policy, 34, 1150-1172.

Sanchez Medina, A. J., Melian Gonzales, A., \& Garcia Falcon, J. M. (2007). Intellectual capital and sustainable development on islands: an application to the case of Gran Canaria. Regional Studies, 41(4), 473-487.

Schiuma, G., \& Lerro, A. (2008). Knowledge-based capital in building regional innovation capacity. Journal of Knowledge Management, 12(5), 121-136.

Schiuma, G., Lerro, A., \& Carlucci, D. (2005). An interfirm perspective on intellectual capital. In B. Marr (Ed.), Perspectives in intellectual (pp. 155-169). Boston: Elsevier Butterworth-Heinemann.

Schiuma, G., Lerro, A., \& Carlucci, D. (2008). The knoware tree and the region intellectual capital index: An assessment within Italy. Journal of Intellectual Capital, 9(2), 283-300.

Spence, L. J., \& Schmidpeter, R. (2003). SMEs, social capital and the common good. Journal of Business Ethics, 45(1-2), 93-108.

Spence, L. J., Habisch, A., \& Schmidpeter, R. (2004). Responsibility and social capital: The world of small and medium sized enterprises. Palgrave: MacMillan.

Spence, L. J., Schmidpeter, R., \& Habisch, A. (2003). Assessing social capital: Small and medium sized enterprises in Germany and the U.K. Journal of Business Ethics, 47(1), 17-29.

Storper, M. (2005). Society, community, and economic development. Comparative International Development, 39(4), 30-57.

Teece, D. J. (2000). Strategies for managing knowledge assets: The role of firm structure and industrial context. Long Range Planning, 33(1), 35-54.

Tomaney, J., \& Ward, N. (2000). England and the "new regionalism". Regional Studies, 34(5), 471-478.

Unioncamere. (2014). La vetrina della trasparenza (The showcase of transparency). Retrieved from http://www.csr.unioncamere.it World Commission on Environment and Development. (1987). Our common future. Oxford: Oxford University Press.

Yin, R. K. (1994). Case study research: Design and methods (2nd ed.). Thousand Oaks: Sage Publications. 